\title{
Strategies to Fund Your Child's College Education: Using Savings and Tax-Advantaged Vehicles ${ }^{1}$
}

\author{
Jessica McCumber, Jorge Ruiz-Menjivar, Martie Gillen, and Sarah M. Ellis²
}

\section{Introduction}

The average annual cost of tuition and fees is $\$ 33,480$ at private colleges, $\$ 9,650$ for in-state students at public universities, and $\$ 24,930$ for out-of-state students at public universities (CollegeBoard, 2019). This brings us to the importance of planning for college education. It is never too soon to explore funding options for college educations, whether your child is a newborn or is in middle school. You are more likely to be prepared to fund your child's education if you start planning earlier.

This publication describes and discusses the following accounts that allow you to pay for college while taking advantage of tax and savings opportunities:

\section{College Savings}

\section{UGMA/UTMA Assets}

\section{Coverdell Education Savings Accounts (CESA)}

4. Traditional or Roth IRA

5. The Health and Education Exclusion Trust (HEET)

6. Crummey Trust

7. Series EE and Series I Savings Bond

\section{College Savings Plans}

What is a 529 plan?

- A 529 plan is a tax-advantaged saving plan (also known as a "Qualified Tuition Plan") that is sponsored by states, state agencies, or educational institutions.

- After tax money is invested into the plan and withdrawals are used for qualified higher education, expenses are tax-free. Earnings are not subject to federal tax.

- Two types of 529 plans exist:

- Prepaid Tuition Plans

- Education Savings Plans

- Be sure to explore your options and ask about annual fees and operating costs up front.

- More than 30 states in the US offer these plans, which vary for each state. You do not have to purchase in your own state, but it may still be the best option.

1. This document is FCS3353, one of a series of the Department of Family, Youth and Community Sciences, UF/IFAS Extension. Original publication date June 2019. Visit the EDIS website at https://edis.ifas.ufl.edu for the currently supported version of this publication.

2. Jessica McCumber, undergraduate student; Jorge Ruiz-Menjivar, assistant professor; Martie Gillen, associate professor, Department of Family, Youth and Community Sciences; and Sarah M. Ellis, Extension agent I, UF/IFAS Extension Citrus County; UF/IFAS Extension, Gainesville, FL 32611.

The use of trade names in this publication is solely for the purpose of providing specific information. UF/IFAS does not guarantee or warranty the products named, and references to them in this publication do not signify our approval to the exclusion of other products of suitable composition.

The Institute of Food and Agricultural Sciences (IFAS) is an Equal Opportunity Institution authorized to provide research, educational information and other services

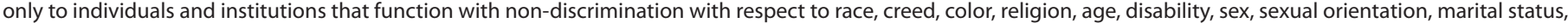

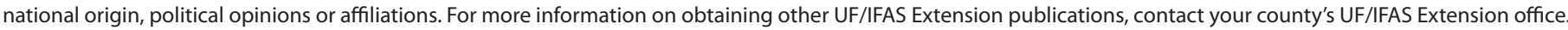
U.S. Department of Agriculture, UF/IFAS Extension Service, University of Florida, IFAS, Florida A \& M University Cooperative Extension Program, and Boards of County Commissioners Cooperating. Nick T. Place, dean for UF/IFAS Extension. 
Table 1. Prepaid plan.

\begin{tabular}{|l|l|}
\hline \multicolumn{1}{|c|}{ Advantages } & \multicolumn{1}{|c|}{ Disadvantages } \\
\hline $\begin{array}{l}\text { Buying future tuition credits and } \\
\text { mandatory fees at the current } \\
\text { tuition rate to avoid climbing } \\
\text { prices. }\end{array}$ & $\begin{array}{l}\text { Might not be able to use for } \\
\text { room and board. } \\
\text { Purchased for eligible schools. If } \\
\text { your child does not attend one } \\
\text { of those universities, you get } \\
\text { your money back, but it may not } \\
\text { have grown much. }\end{array}$ \\
\hline $\begin{array}{l}\text { Depending on your state, } \\
\text { contributions are often tax- } \\
\text { deductible and earnings that } \\
\text { grow are tax-deferred. }\end{array}$ & $\begin{array}{l}\text { Most require residency in the } \\
\text { state of purchase. }\end{array}$ \\
\hline $\begin{array}{l}\text { Most plans are sponsored or } \\
\text { guaranteed by the state. }\end{array}$ & $\begin{array}{l}\text { Not guaranteed by the federal } \\
\text { government. If the plan's } \\
\text { sponsor has a financial shortfall, } \\
\text { you may lose some or all of your } \\
\text { money. }\end{array}$ \\
\hline $\begin{array}{l}\text { Most set lump sum and } \\
\text { installment payments prior to } \\
\text { purchasing the plan based on } \\
\text { the age of the beneficiary and } \\
\text { the number of years of tuition } \\
\text { being purchased. Easy to plan. }\end{array}$ & $\begin{array}{l}\text { Most have limited enrollment } \\
\text { period and age limits on the } \\
\text { beneficiary. }\end{array}$ \\
\hline
\end{tabular}

Table 2. Education savings plans.

\begin{tabular}{|l|l|}
\hline \multicolumn{1}{|c|}{ Advantages } & \multicolumn{1}{c|}{ Disadvantages } \\
\hline $\begin{array}{l}\text { No residency requirement or age } \\
\text { limits. Enrollment open year- } \\
\text { round. }\end{array}$ & $\begin{array}{l}\text { Sponsored by state, but not } \\
\text { backed by a state guarantee. } \\
\text { Subject to market risk and could } \\
\text { potentially decline in value. }\end{array}$ \\
\hline $\begin{array}{l}\text { Covers all “higher education } \\
\text { expenses” which include tuition, } \\
\text { fees, room and board, and } \\
\text { textbooks. }\end{array}$ & $\begin{array}{l}\text { The tuition price is current, not } \\
\text { locked at the time of opening } \\
\text { the account. }\end{array}$ \\
$\begin{array}{l}\text { Note: This type of account is viewed as your asset, not as your child's } \\
\text { asset. This fact will become important when your child is being } \\
\text { considered for financial aid. }\end{array}$ \\
\hline
\end{tabular}

\section{UTMA/UGMA Accounts}

What do these letters stand for and what do they mean?

- Uniform Transfer to Minors Act Account and Uniform Gift to Minors Act Account

- These are custodial accounts that essentially act as a trust for your child. They can contain stocks, bonds, annuities, cash, and other assets reserved for your child until they come of age.

- Any money in these accounts will be counted as a part of the taxable estate of the custodian before the child reaches the age of trust termination.

- The income from a custodial account must be reported on the child's tax return at the child's rate as determined by the Kiddie Tax rules.
Table 3. UTMA/UGMA Accounts

\begin{tabular}{|l|l|}
\hline \multicolumn{1}{|c|}{ Advantages } & \multicolumn{1}{c|}{ Disadvantages } \\
\hline $\begin{array}{l}\text { Can contribute as much as you } \\
\text { want (amounts above } \$ 14,000 \\
\text { per year will incur federal gift } \\
\text { tax). Earnings will be taxed at the } \\
\text { child's rate. }\end{array}$ & $\begin{array}{l}\text { No state deductions received } \\
\text { for money contributed. You will } \\
\text { not be exempt from taxes on the } \\
\text { earnings. }\end{array}$ \\
\hline $\begin{array}{l}\text { Anyone can open or contribute } \\
\text { on behalf of a child. }\end{array}$ & $\begin{array}{l}\text { Significant impact on financial } \\
\text { aid. The account belongs to the } \\
\text { child, and } 20 \% \text { of the money will } \\
\text { count against financial aid. }\end{array}$ \\
\hline $\begin{array}{l}\text { No penalty if the assets are not } \\
\text { used for college. }\end{array}$ & $\begin{array}{l}\text { No restrictions on the use of } \\
\text { the money. When the minor } \\
\text { becomes an adult, they are } \\
\text { free to use the money for any } \\
\text { purpose. }\end{array}$ \\
\hline
\end{tabular}

Note: This type of account is viewed as the asset of your child. This fact will become important when your child is being considered for financial aid and may affect the amount of aid offered.

\section{Coverdell Education Savings Account (CESA)}

What is a CESA?

- A trust or custodial account that is established to pay for a beneficiary's qualifying education expenses.

- Recognized as an asset owned by the beneficiary, who can use the principal interest to pay for qualified expenses (tuition, fees, books, supplies, and room and board).

Table 4. Coverdell Education Savings Account (CESA)

\begin{tabular}{|l|l|}
\hline \multicolumn{1}{|c|}{ Advantages } & \multicolumn{1}{c|}{ Disadvantages } \\
\hline $\begin{array}{l}\text { Distributions are tax-free as long } \\
\text { as they do not exceed the cost of } \\
\text { education. }\end{array}$ & $\begin{array}{l}\text { Contributions are limited to } \\
\$ 2,000 \text { per tax year. }\end{array}$ \\
\hline $\begin{array}{l}\text { The beneficiary can claim the } \\
\text { Hope Credit or Lifetime Learning } \\
\text { Credit for qualified education } \\
\text { expenses even if they are } \\
\text { withdrawing from a CESA. }\end{array}$ & $\begin{array}{l}\text { Beneficiary cannot claim the } \\
\text { credit for the same educational } \\
\text { expenses covered by a CESA. }\end{array}$ \\
\hline $\begin{array}{l}\text { Accounts of beneficiaries with } \\
\text { special needs are not subject to } \\
\text { age restrictions on contributions } \\
\text { and withdrawals. }\end{array}$ & $\begin{array}{l}\text { Beneficiary must be under } 18 \\
\text { years of age when the account is } \\
\text { established. If the balance is not } \\
\text { used prior to the beneficiary's } \\
\text { 30 th } \text { birthday, account owner will } \\
\text { incur tax and penalty fees. }\end{array}$ \\
\hline
\end{tabular}

\section{Traditional or Roth IRA}

What is an IRA?

- IRA stands for individual retirement account. Most people think that these accounts are simply great ways to save for retirement. However, the accounts can also be used to cover educational expenses. 
Table 5. Traditional or Roth IRA

\begin{tabular}{|l|l|}
\hline \multicolumn{1}{|c|}{ Advantages } & \multicolumn{1}{|c|}{ Disadvantages } \\
\hline $\begin{array}{l}\text { Withdrawals from IRAs, including } \\
\text { Roth IRAs, are exempt from the } \\
10 \% \text { early withdrawal penalty if } \\
\text { the amount is used specifically } \\
\text { for qualified educational } \\
\text { expenses (tuition, fees, room } \\
\text { and board). }\end{array}$ & $\begin{array}{l}\text { Only contribution portions of } \\
\text { the traditional IRA balances } \\
\text { can be withdrawn tax-free for } \\
\text { educational expenses. Anything } \\
\text { withdrawn that exceeds the } \\
\text { total contributions (earnings) } \\
\text { will be taxable for those younger } \\
\text { than 59.5 years old. }\end{array}$ \\
\hline $\begin{array}{l}\text { Leftover funds after withdrawal } \\
\text { for educational expenses can } \\
\text { be converted into retirement } \\
\text { income. }\end{array}$ & $\begin{array}{l}\text { Contribution limit is } \$ 5,500 . \\
\text { Retirees may not be able to } \\
\text { partake as they must have } \\
\text { earnings to contribute. }\end{array}$ \\
\hline Can be passed on to heirs. & $\begin{array}{l}\text { Individuals with income } \\
\text { exceeding } \$ 114,000 \text { are } \\
\text { prohibited from using a Roth } \\
\text { IRA. }\end{array}$ \\
\hline
\end{tabular}

\section{The Health and Education Exclusion Trust (HEET)}

\section{What is a HEET?}

- A trust established either during an individual's lifetime or by their will upon death to provide payments for medical expenses and educational expenses for their descendants (two or more generations younger).

- Designed to minimize the generation-skipping tax (GST).

- This method is appropriate for grandparents seeking to make transfers to their grandchildren.

Table 6. The Health and Education Exclustion Trust (HEET)

\begin{tabular}{|l|l|}
\hline \multicolumn{1}{|c|}{ Advantages } & \multicolumn{1}{c|}{ Disadvantages } \\
\hline $\begin{array}{l}\text { Allows funds to be paid to } \\
\text { benefit the grandchildren even } \\
\text { if the owner of the trust may } \\
\text { have used up their generation- } \\
\text { skipping exemption. }\end{array}$ & $\begin{array}{l}\text { Funds from the trust must be } \\
\text { paid directly to the educational } \\
\text { institution itself for tuition. }\end{array}$ \\
\hline $\begin{array}{l}\text { No limitation on the amounts } \\
\text { that can be paid for tuition and } \\
\text { medical expenses. }\end{array}$ & $\begin{array}{l}\text { Cannot be used for parent-to- } \\
\text { child giving. }\end{array}$ \\
\hline
\end{tabular}

\section{Crummey Trust}

What is a Crummey trust?

- A trust established to gift money to a minor while maintaining a certain degree of control over how the assets are distributed.
Table 7. Crummey Trust

\begin{tabular}{|l|l|}
\hline \multicolumn{1}{|c|}{ Advantages } & \multicolumn{1}{c|}{ Disadvantages } \\
\hline $\begin{array}{l}\text { Gives the donor control over } \\
\text { the timing of the distributions. } \\
\begin{array}{l}\text { Accumulated trust assets can be } \\
\text { held in trust for the beneficiary } \\
\text { until they are more mature. }\end{array}\end{array}$ & $\begin{array}{l}\text { Each time a donor contributes } \\
\text { to the trust, a notice of a right of } \\
\text { withdrawal must be provided to } \\
\text { the beneficiary or guardian, and } \\
\text { they have about 30 to 60 days } \\
\text { to act. }\end{array}$ \\
\hline $\begin{array}{l}\text { No penalty if funds are used } \\
\text { for expenses other than higher } \\
\text { education. }\end{array}$ & $\begin{array}{l}\text { Expensive to set up because it } \\
\text { is a more complex method and } \\
\text { must be drafted by an attorney. }\end{array}$ \\
\hline $\begin{array}{l}\text { This trust can have multiple } \\
\text { beneficiaries. }\end{array}$ & $\begin{array}{l}\text { This type of trust may affect the } \\
\text { beneficiary's ability to qualify } \\
\text { for financial aid because the } \\
\text { distributions are considered } \\
\text { income. }\end{array}$ \\
\hline
\end{tabular}

\section{Series EE and Series I Savings} Bond

What are Series EE and Series I Savings Bonds?

- Two series of savings bonds currently offered by the US Treasury.

- Can still purchase paper Series I bond with a tax refund at face value; paper Series EE bonds are no longer available.

- Both can be purchased in electronic format for face value for any value over $\$ 25$ to the penny (e.g., a $\$ 50$ bond would cost you $\$ 50)$.

- The savings bond education tax exclusion permits qualified taxpayers to leave out partial or full interest paid upon redeeming the bonds (purchased after 1989) from their gross income, when the bond owner pays for qualified educational expenses within the same tax year in which the bonds were redeemed.

Table 8. Series EE and Series I Savings Bond

\begin{tabular}{|l|l|}
\hline \multicolumn{1}{|c|}{ Advantages } & \multicolumn{1}{c|}{ Disadvantages } \\
\hline $\begin{array}{l}\text { Both principal and interest } \\
\text { can be cashed in tax-free for } \\
\text { paying college tuition for the } \\
\text { beneficiary. }\end{array}$ & $\begin{array}{l}\text { Qualified expenses include only } \\
\text { tuition and fees. Room and } \\
\text { board and books are not eligible. }\end{array}$ \\
\hline $\begin{array}{l}\$ 15,000 \text { limit for single clients } \\
\text { and } \$ 30,000 \text { for married couples. }\end{array}$ & $\begin{array}{l}\text { Early withdrawal penalty } \\
\text { associated with the bonds in the } \\
\text { first five years. }\end{array}$ \\
\hline & $\begin{array}{l}\text { These bonds offer a low rate of } \\
\text { return. }\end{array}$ \\
\hline & $\begin{array}{l}\text { The interest income exclusion } \\
\text { is phased out at higher income } \\
\text { levels, based on the adjusted } \\
\text { gross income. For } 2018, \text { the } \\
\text { exclusion completely phased } \\
\text { out at } \$ 92,000 \text { if filing single and } \\
\text { at } \$ 147,750 \text { if filing jointly. Note } \\
\text { that these limits vary by year. }\end{array}$ \\
\hline
\end{tabular}




\section{References}

CollegeBoard. (2019). Average Published Undergraduate Charges by Sector and by Carnegie Classification, 2018-19. Retrieved from https://trends. collegeboard.org/college-pricing/figures-tables/ average-published-undergraduate-charges-sector-2018-19

Gutter, M., \& Gillen, M. (2015). Education savings vehicles. In C. R. Chaffin (Ed.), Financial Planning Competency Handbook (pp. 145-152). Hoboken, NJ: John Wiley \& Sons, Inc. 